\title{
Commandants' Managerial Capacity and Workers Productivity in Nigeria Police Force Schools.
}

\author{
B.J. Ojo. (PhD)
}

\begin{abstract}
:
The purpose of this study is to evaluate the commandant's managerial capacity as if relates to workers productivity with a view to determining whether their calling to the education terrain has been justified and to correct certain areas in need of improvement in the Nigeria Police Education set up. In doing this, the study took in to cognizance the managerial process that could lead to high teacher productivity in relation to high academic performance of students The study found out that significant relationship exists between commandant Managerial capacity and teacher productivity with a Pearson correlation value of 0.284 and value of 0.001 level of significance. Other factors like experience and qualifications were found to be necessary pre-requisites for the appointment of heads of schools with chi-square value of 9.712 and p-level of 0.021 significance. Female teachers productivity was found to be lower than that of their male counterparts. In view of the findings, the study made some useful suggestions and recommendations.
\end{abstract}

\section{Background of the Study}

Organizations need managers, just as a car needs a driver, whether formal or informal, organization deprived of managers would quickly cease to function effectively. It is against this backdrop that the school system in the Nigeria police shall be viewed. The development of human beings demands a lot of capability and capacity by the 
school principals. Their ability to withhold, contain and contend with the various school activities will depend largely on their managerial capability. This is the more reason why appointments of these school managers should be based on capacity of the individuals to rise to a high level of managerial competence.

Experience has shown that it appeared that those appointed to the position of principalship were appointed without giving much consideration to some managerial criteria such as training, around which revolves competence, experience, ability to plan, organize, coordinate, motivate, control, administer and supervise. As a result it appeared that those so appointed as principals have to gamble with their jobs before they could gain the required experience. This Type of appointment was viewed by Ekpo as being detrimental to the well being of our school systems when he declared that "our secondary schools do not generally realize optimum productivity because some principles, state schools board and communities tend to see school management simply as common sense affairs. In order to perform effectively in their roles, all principals and would be principals should be familiar with the operation and interpretation of the content of organizational climates".

Experience has equally shown that the appointments of some of these principals were regarded as a 'matter of course' and 'common sense affair' without the required managerial guidelines. This often results in a situation resembling the "peter principle" where by people are routinely promoted into posts where they cannot function effectively. These managers appear not to have been properly groomed before they are appointed and are saddled with managerial roles they are not familiar with. 
The Inspector Generals expectations from these managers range from their ability to plan and favorably compete with the other schools in and outside of the country. Inexperienced as some of them may be, they are expected to preside over hundreds of academic staff and thousands of students in their schools. In essence, the school heads who are leaders within this education enterprise would be judged by the way they are able to carry out their managerial responsibilities. The measure of their supervision would also be judged by the welfare of their staff and students.

Fred Luthans and Alexander Stajkovic in Hughes et al (2006) state that the real challenge for leaders is to manager human resources as effectively as possible in order to attain world class performance. Both teachers and students would look up to their commandant (who is the leader) to provide for their required needs, create an atmosphere that will ensure the effective management of curriculum and its application to students making sure that at every stage, the curriculum is relevant and suitable to the age, maturity readiness, aptitude and interest of the learners. He has to show example by patience, amicability, kindness, considerations and genuine of interest in the problems of his team. These qualities would facilitate good human relations effective administration and the desired support from the subordinates.

In explaining the relationship that exists between leadership and worker performance, Hughes, et al (2006) came up with a model which explains why some leaders enjoy good followership and others do not. Why some leaders do not get the followers to exhibit enough of those behaviors needed for the team to succeed and why some leaders are capable of getting followers to go above and 
beyond the call of duty. They conclude that the best leaders may well be those who can motivate workers to perform at a high level while maintaining an equally high level of job satisfaction. Peter Drucker Cited in Hughes et al (2006) says "Executives owe it to their organization and fellow workers not to tolerate nonperforming people in important jobs". Beverly Kaye (Hughes 2006) concludes that people (worker) don't leave companies rather they leave bad leaders. Therefore as a school manager the commandant must motivate and encourage the workers to give their best, prepare them for emergencies that would require creativity, get them to have a clear focus and push them beyond their book knowledge, bringing out the best in them in order that the academic and the over all goal of their institution might be achieved.

\section{Fig. 1 Relationship between Leadership, Job Satisfaction, and Performance.}
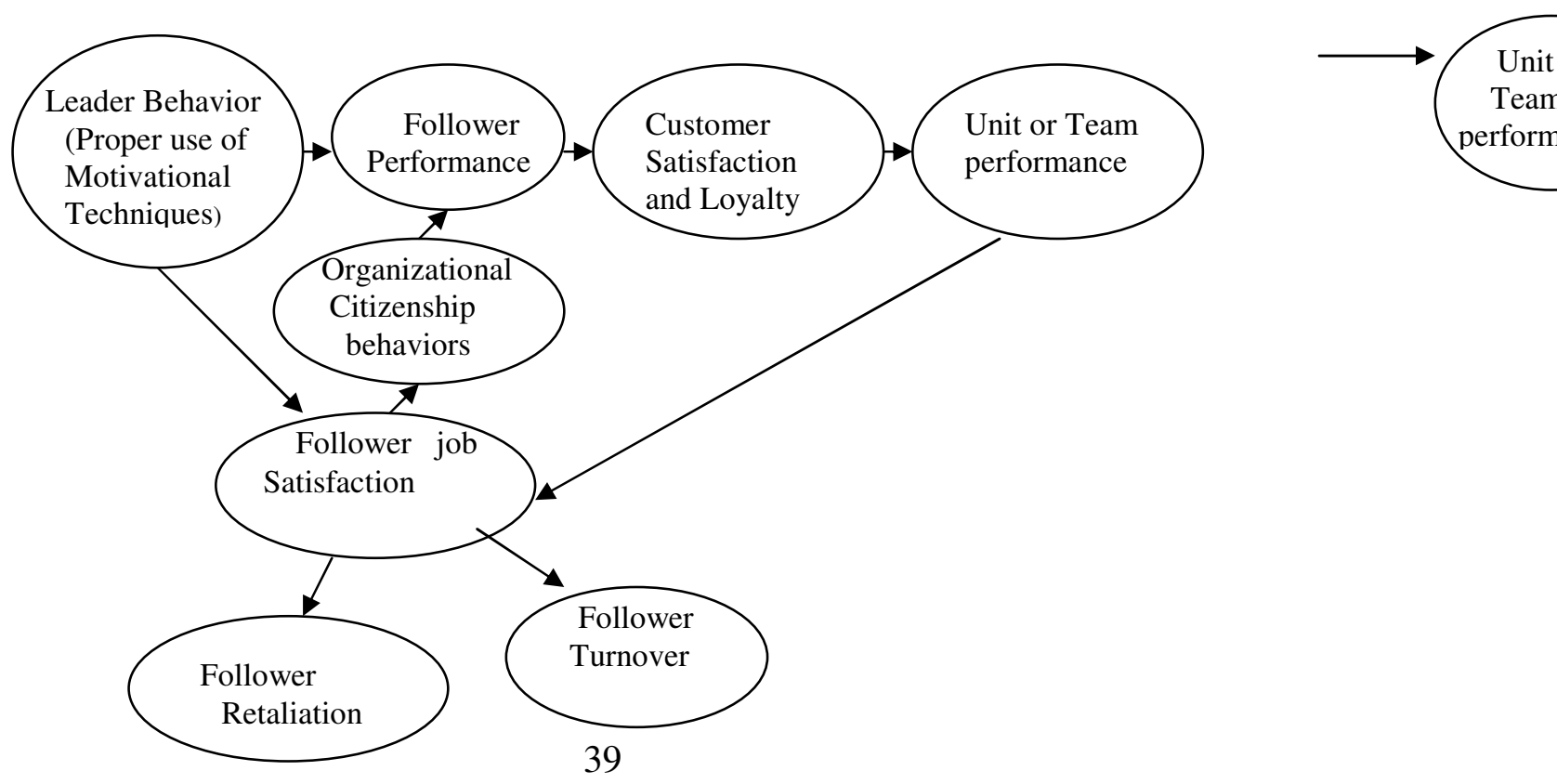
Source : - Adapted from Hughes, et al (2006) motivation, satisfaction, and performance. Pp.243

\section{Statement of Problem:}

Some educationists have found if expedient for analytical purpose, to categories some schools as special schools. The schools so categorized, are established with the main objective of serving as catalysts in the field of educational development. They include schools that are research and development oriented; schools attempting a change in the social status quo; schools in the business of modernizing social values and attitudes; and schools whose outputs and actions have long term developmental impact in their domain. The Police Children/ Secondary schools established by the Inspector General of Police fall within this category. (Jaja 1998). In his own opinion, Taiwo (1982) submitted that in the new educational dispensation of 6-3-34, the principals would be the first to admit that the administration of these type of schools demand experience, new techniques special personal qualities, leadership qualities, professional competence, knowledge of the local community, ability to move with the times and foresight into the future.

The managerial capacity of school managers would determine to a greater extent, the amount of efforts teachers put into their day-to-day activities for maximum results.

On this fact and coupled with the original aims establishing the schools, the study sets out to examine among other things:

- the effectiveness of these schools managers, who with little or no experience found themselves as heads of schools; 
- the extent to which the original objectives for setting up the schools have been achieved.

- and to find out the impact of the Commandants' managerial capacity on the performance of the staff and students of these institutions.

\section{Research Questions.}

Based on the problem stated above, the following questions would be addressed.

1. What are the major criteria used for the appointment of commandants as school heads?

2. Do these commandants' posses and use managerial capacity like controlling, supervising, administering, planning and coordinating?

3. Is there any relationship between commandant's managerial capacity and worker's productivity?

4. What are the aspects of the commandant managerial capacity that teachers perceive as encouraging them towards maximum output in their works?

\section{Hypothesis}

The study was intended to find the relationship between commandants' managerial capacity and teacher productivity. The major hypothesis for this study was that commandants' managerial capacity will not significantly influence teachers' performance in Nigeria Police schools. To this end, the following directional hypotheses were proposed for testing;

Ho1: The managerial capacity of commandants in police schools will be rated significantly high.

Ho2: The level of teacher productivity in police schools will be rated as significantly high. 
Ho3: There will be no significant relationship between commandants managerial capacity and teacher productivity in police schools.

Ho4: Experience and qualifications will not significantly affect the appointments of the commandants as school managers.

\section{Methodology:-}

The study was to find out the correlation between the commandant's managerial capacity and teacher productivity in the Nigeria police force schools. Hence the study is correlational; the design will be correlational ex-post facto which according to Kerlinger (1977) is a systematic empirical inquiry in which the scientist does not have direct control, of independent variables because their manifestations have already occurred or because they are inherently not manipulable. Inferences about - relations among variables are made without direct intervention from concomitant variation of independent and dependant variables. Kerlinger further explained that, if ' $x$ ' then ' $y$ ' the researcher observes ' $y$ ' to see if concomitant variation, the variation expected or predicated from the variation in ' $x$ ' occurs. If it does, this is the evidence for validity of the proposition " $x$ " $\rightarrow$ " $y$ " meaning "if $x$ then $y$ ".

The subjects for this study was taken from the twelve zones to which the force was divided nationally, thirty five (35) schools were sampled using stratified probability proportion to size (SPPS). The heads of these schools, three hundred and fifty teachers and six hundred students constituted the subject of this study. Longitudinal data were collected through primary and secondary sources and analyzed using Pearson product movement Correlation, t- test and percentage rating. The four hypotheses formulated for 
the study were tested at 0.05 level of significance. Results and statistical analysis of data collected are presented below:

\section{Results and Discussion}

Ho1: The Managerial Capacity of Commandants in the Nigeria Police Schools will be rated as Significantly High.

Table 1: Teachers Perception of Commandants' Managerial capacity

\begin{tabular}{|c|c|c|c|c|c|c|}
\hline \multicolumn{7}{|c|}{ RA T1NG } \\
\hline S/No & Variables & High & & Low & & \\
\hline & & $x$ & $\%$ & $x$ & $\%$ & \\
\hline 1 & Planning & 3.42 & 77.4 & 1.0 & 22.6 & $\mathrm{HIGH}$ \\
\hline 2 & organizing & 11.80 & 53.0 & 4.96 & 47.0 & $\mathrm{HIGH}$ \\
\hline 3 & Co-coordinating & 5.94 & 49.6 & 2.28 & 50.4 & $\mathrm{HIGH}$ \\
\hline 4 & Motivating & 34.59 & 51.3 & 12.22 & 48.7 & $\mathrm{HIGH}$ \\
\hline 5 & Controlling & 6.0 & 56.5 & 2.0 & 43.5 & $\mathrm{HIGH}$ \\
\hline 6 & Administration & 31.96 & 61.7 & 11.93 & 38.3 & $\mathrm{HIGH}$ \\
\hline 7 & Supervision & 12.77 & 53.9 & 3.78 & 46.1 & $\mathrm{HIGH}$ \\
\hline 8 & Intervention & 5.63 & 69.6 & 2.18 & 30.4 & $\mathrm{HIGH}$ \\
\hline 9 & Social & 18.33 & 66.1 & 6.50 & 33.9 & $\mathrm{HIGH}$ \\
\hline 10 & Bureaucracy & 27.36 & 60.9 & 12.50 & 39.1 & $\mathrm{HIGH}$ \\
\hline
\end{tabular}

Results in table 1 above show that commandants' managerial capacity was rated significantly high by the teachers. Out of ten items, nine $(90 \%)$ were found to be high by the teachers while only one $(10 \%)$ was found to be lower; therefore the hypothesis is accepted. 
Ho2: Perception of the Level of Teacher Productivity will be Rated as Significantly high.

Table 2: Students' Perception of Teacher Productivity

\begin{tabular}{|c|c|c|c|c|c|c|}
\hline \multirow{4}{*}{$\begin{array}{l}\text { S/N } \\
0\end{array}$} & \multirow{4}{*}{ Variables } & \multirow{2}{*}{\multicolumn{5}{|c|}{ Ratings }} \\
\hline & & & & & & \\
\hline & & \multicolumn{2}{|l|}{ High } & \multicolumn{2}{|c|}{ Low } & \\
\hline & & $\mathrm{X}$ & $\%$ & $\mathrm{X}$ & $\%$ & \\
\hline 1 & Academic Pursuit & 27.85 & 95.7 & 13.08 & 4.3 & High \\
\hline 2 & Guidance \& Counseling & 22.05 & 93.5 & 8.50 & 6.5 & High \\
\hline 3 & Student Record & 6.80 & 91.4 & 2.40 & 8.6 & High \\
\hline 4 & Lesson Preparation & 3.25 & 82.7 & 1.0 & 17.3 & High \\
\hline 5 & Dissatisfaction & 7.98 & 68.6 & 3.74 & 31.4 & High \\
\hline 6 & Staff Adequacy & 3.22 & 67.4 & 1.0 & 32.6 & High \\
\hline 7 & Extra Admin. Duties & 3.12 & 55.0 & 1.0 & 45.0 & High \\
\hline 8 & Frequent transfers & 3.08 & 82.3 & 1.00 & 17.7 & High \\
\hline 9 & $\begin{array}{ll}\begin{array}{l}\text { Female } \\
\text { performance }\end{array} & \text { teachers } \\
\end{array}$ & 3.13 & 73.3 & 1.0 & 26.7 & High \\
\hline 10 & Male teachers output & 3.43 & 86.7 & 1.0 & 13.3 & High \\
\hline
\end{tabular}

From table 2 above, out of ten areas of focus, all (100\%) were rated as significantly high by the observers, this shows that the teachers were performing despite the conditions of service they are subjected to. However, $80 \%$ of the items were rated positively high while (2 items) $20 \%$ were rated negatively high and positively low. The hypothesis is therefore accepted.

Ho3: There will be no Significant Relationship between Commandants' Managerial Capacity andTeachers Productivity.

Table 3: Relationship between Teacher Productivity and Commandants' Managerial Capacity

\begin{tabular}{|l|l|l|}
\hline Teacher productivity & Teacher prod. & C.M.C \\
& 1.00000 & 0.284 \\
& 0.0 & 0.0001 \\
\hline Commandant Managerial & 0.284 & 1.000000 \\
capacity & 0.0001 & 0.0 \\
\hline
\end{tabular}


The Pearson correlation matrix table above shows a correlation co-efficient of 0.284 and the $p$-value $=0.0001$ $(P<0.05)$ which indicates a significant relationship. In aiming at the above result, a Pearson co-relation analysis was adopted. The correlation coefficient between $\mathrm{x}$ and $\mathrm{y}$ shows a positive correlation of 0.284 with the $p$ value $=0.0001$ $(P<0.05)$, which indicates that a strong association do exist between $x$ and $y$. The hypothesis is hereby rejected.

Ho4: Experience and Qualifications will not Significantly Affect the Appointments of Schools Commandants in the Nigeria Police Schools. Table 4: Effects of Experience on Appointment of
Commandants

\begin{tabular}{|c|c|c|c|c|c|}
\hline \multirow[t]{2}{*}{ Experience in years } & \multicolumn{4}{|c|}{ Scores } & \\
\hline & SA & $A$ & $\mathrm{D}$ & SD & Total \\
\hline $0-5$ years & 20 & 2 & 10 & 20 & 52 \\
\hline $6-10$ years & - & 8 & 6 & 14 & 28 \\
\hline $11-15$ years & 8 & 4 & 22 & 28 & 62 \\
\hline $16-20$ years & - & 4 & 6 & 2 & 12 \\
\hline $21-30$ years & - & - & 2 & - & 2 \\
\hline Total & 28 & 18 & 46 & 64 & 156 \\
\hline
\end{tabular}

In finding the level of significance of this result the chi-square value was computed at 48.637

with a DF of 12 and the probability level of 0.0000 : therefore $\mathrm{P}<0.05$. The result from the table indicates that experience is very critical to the appointment of commandants in Police schools. 
Table 5: Effects of Qualification on the Appointments of Commandants in Police Schools.

\begin{tabular}{|l|l|l|l|l|l|}
\hline Qualification & \multicolumn{5}{|c|}{ Scores } \\
\hline & SA & A & D & SD & Total \\
\hline 1st Degree and above & 4 & 4 & 20 & 14 & 42 \\
\hline Non-Degree & 24 & 14 & 26 & 50 & 114 \\
\hline Total & 28 & 18 & 46 & 64 & 156 \\
\hline
\end{tabular}

When the chi-square $\left(x^{2}\right)$ was calculated, a 9.712 value was arrived at with a degree of freedom (DF) of 3; the probability level was 0.021 which was less than 0.05 . This indicates that qualification is very crucial and very important in the appointment of commandants in the NPF schools. From the results, it would be noted that one of the major findings of the study shows that commandants' managerial capacity is significantly high.

The finding agrees with Umaru (1986) that the most vital requirements for success is for each principal to become more conscious of his managerial functions. Teachers see their commandants as school managers with high ratings given to the nine dimensional areas of commandant managerial capacity of planning, organizing, co-coordinating, motivating, controlling, administering, supervising, intervening and social. The school managers are equally unlike what Simon described as: "heads carrying too big a burden so as to live up to the traditional ideas of being a good headmaster." Simons' description implied lack of delegation of authority which could lead to role strain or role overload of heads of schools. With the analysis of the result shown in table one; perceptions of commandant managerial capacity were rated high. There is however, the need for some supportive aids from the authorities controlling the schools. 
Secondly, for the purpose of this study, the areas of teacher productivity investigated were all processes to an end and not the end results by themselves. The study decided to make students evaluate their teachers' instructions within the school system. This is in line with Lehman's (1961) submission that, "students are perceptive and they become more so when they realize that their opinions are seriously regarded". Gustard (1966) agrees with this submission that students are virtually the only direct observers and are in the position to assess their teachers' performances should they be asked the right questions. While Costing et al (1971) declared that students ratings of instructors are generally found to be stable, internally reliable and valid with respect to many criteria of teaching effectiveness. For these reasons, the assessment of high teacher productivity of $80 \%$ rated by students can be said to be valid, reliable and could stand the test of time. From the result, students did not feel that teachers showed dissatisfaction with their job or talk irrelevancies in the class. The findings of this study dose not quite agree with Madubuike's (1980) observation that teachers lack a sense of devotion and direction, they spend their time running around for contracts and engage in petty trading. These traits naturally detract from their effectiveness (Productivity). While one might not completely dismiss Madubuike's assumption; it has not been proved by this study. It is possible that teachers might be engaged in petty trading to make ends meet, but that has not led to their being ineffective. On the relationship that exists between commandant managerial capacity and teacher productivity, it is assumed that commandants as school heads would always provide the desired climate conducive to high teacher productivity. 
From the results in table 3 , there was a high positive relationship between commandants' managerial capacity and teacher productivity in the Nigeria Police force schools. With the criteria used for managerial capacity and teacher productivity, commandants' managerial capacity was perceived to be relatively positive enough for higher academic goals. The managerial capacity had been proved to have assured high teacher productivity in terms of output for high academic goals.

Finally, unlike the conventional schools where the ministry of education and the School Management Boards control schools, appoint staff, promote them and oversee all other staff welfare, the sole owner and controller of the N.P.F schools is the Inspector General of Police (IGP). He appoints the Force Education Officer (FEO) like any other State Command Commissioner of Police, he appoints commandants and all heads of schools like any other Divisional Police Officers (DPO), do promotion, Staff welfare etc.

One of the problems this study sets out to find solution to was whether experience and qualification had any significant influence on the appointments of these commandants. From the findings of the study, there was no significant difference between the perceptions of the younger teachers and the old teachers on the appointments of these school heads. The notion that appointments were based on whom you know, your religion, and where you come from was not statistically supported. This implies that qualifications are considered for appointment of school managers. This is in line with UNESCO's recommendations that:

Posts of responsibility in education such as that of inspectors, educational administrators, director of education or other posts of special responsibility should be given, as far as possible, to experienced teachers. 


\section{Conclusions and Recommendations:}

The study had been able to establish a relationship between commandants' managerial capacity and teachers productivity in Police schools. In the study both the commandants managerial capacity and the teacher productivity variables had been seen as processes which if well co-coordinated could lead to high output in the academic and social goals of Police School system in Nigeria.

On the basis of the foregoing discussions, this study recommends that the school heads should not be solely held responsible for any poor academic performance in the future. Both teachers and school heads are capable of high academic and social performance if provided with the required supportive aids and motivational incentives by the controlling agencies. As much as possible appointments of school heads should be based on qualification and experience.

\section{References}

Becerly Kaye in Hughes, et al (2006) Leadership - Enhancing the Lessons of Experience (5th Edition). New Delhi:

Tata McGraw - Hill Publishing Company Limited.

Costing, et al (1971): "students Rating of College Teaching Reliability, Validity and Usefulness", Review of Education Research, vol. 41.

Fred Luthans \& stajkovic, A. in Hughes, et al (2006) Leadership - Enhancing the Lessons of Experience (5th Edition ). New Delhi: Tata McGraw - Hill Publishing Company Limited.

Gustard, J. W. (1986): "Evaluation of Teaching Performance: Issues and Possibilities. Improving College Teaching Aids and Impediment." Background Paper of the American Council on Education, 49th Annual meeting. 
Washington: The Council.

Hughes, et al (2006): Leadership - Enhancing the Lessons of Experience; 5th edition New Delhi: Tata McGraw- Hill Publishing Company Limited.

Jaja, S.A (1998): Teacher Behavior Modifications in Quality Management System: The Police School Systems in Perspective. Lagos: PEN, FHQ Annex.

Kerlinger Fred (1977): Foundations of Behavioural Research. New York: Rinehart and Winston Inco.

Lehman. I (1961): "Evaluation of instruction" in Paul Dresse et al (eds.) Evaluation of Higher Education. Boston: Houghton Mifflin Co.

Madubuike, I .C (1980) Goodwill Message from the Honorable Minister of Education to the Conference of the Nigeria Union of Teachers, Calabar, 31st March, 1980. In The Nigerian School Master Journal of Nigerian Union of Teachers, Jan -April No. 19.

Taiwo, C.O (1982): "The Principal in the Nigerian Education." West African Journal of Education, Vol. xxiii No.3 1, 2 and 3.

N'Umaru, (Wing Commander) (1986): The Military Governor of Kwara State Speech on "The Opening Ceremony of ANCOPSS Conference". Minutes of all Nigeria Conference of Principals of Secondary Schools, March 31st to April 4th.

UNESCO (1966): "Recommendations Concerning The status of Teachers", UNESCO Inter - Governmental Special Conference on Status of Teachers, Paris.

Peter Druker in Hughes, et al (2006): Leadership Enhancing the Lessons of Experience. (5th Edition). New Delhi: Tata McGraw- Hill Publishing Company Limited. 